\title{
BEITRÄGE ZUR KENNTNIS \\ DES \\ RÖMISCH-ÄGYPTISCHEN \\ GRUNDBUCHRECHTS
}

vON

DR. IUR. HANS LEWALD

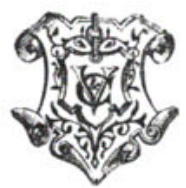

LEIPZIG

VERLAG VON VEIT \& COMP. 
Druck von Metzger \& Wittig in Leipzig. 